\title{
Efficacy of Antibiotics Combined with Biosynthesized Silver Nanoparticles on some Pathogenic Bacteria
}

\author{
Ekbal H. Abdel Hafez ${ }^{1}$, Entesar A. Ahmed ${ }^{2}$, Heba S. Abbas ${ }^{3}$, Rawheya A. Salah El Din ${ }^{4}$ \\ ${ }^{1}$ National Organization for Drug Control and Research (NODCAR), Giza, Egypt \\ ${ }^{2}$ Botany and Microbiology Department, Faculty of Science, Al-Azhar University (Girl Branch), Cairo Egypt \\ ${ }^{3}$ National Organization for Drug Control and Research (NODCAR), Giza, Egypt \\ ${ }^{4}$ Botany and Microbiology Department, Faculty of Science, Al-Azhar University (Girl Branch), Cairo Egypt
}

\begin{abstract}
Biosynthesis of Silver Nanoparticles (AgNPs) has received great attention due to their numerous advantages like being rapid, simple and eco-friendly protocol. In the present study, weused cultures supernatant of pathogenic bacteria and fungi like Staphylococcus aureus 29737 ATCC, Staphylococcus epidermidis 12228 ATCC and Klebsiella pneumoniae 700603 ATCC,as well as cell free filtrate of Fusarium sp. and Aspergillus flavusfor rapid synthesis of silver Nanoparticles.UV- visible spectrometry study revealed the plasma resonance from 420 to $440 \mathrm{~nm}$.Transmission electron microscope of AgNPs showed the mean average size of most particles was 11,29.9, 16.8, 23.4 and $23.4 \mathrm{~nm}$ for Staphylococcus aureus, Staphylococcus epidermidis and Klebsiella pneumoniae, Fusarium sp. and A. flavusrespectively. The Fourier Transmittance Infrared spectrum (FT-IR) confirmedthe reduction of the silver ions and forming stable and control shaped silver nanoparticles due to the protein component resulting from the enzyme nitrate reductase. Results of this study revealed that the synthesized silver nanoparticles have potential antibacterial activity and were also capable of enhancing the efficiencies of some commercial antibiotics.
\end{abstract}

Keywords:Biosynthesis of silver nanoparticles, UV-Vis spectrophotometer, FTIR, TEM antibacterial, antibiotic enhancer

\section{Introduction}

Emerging infectious diseases and the increase in incidence of drug resistance among pathogenic bacteria and fungi have made the search for new antimicrobials inevitable. In the current situation, one of the most promising and novel therapeutic agents are the nanoparticles. The unique physiochemical properties of the nanoparticles combined with the growth inhibitory capacity against microbes has led to the upsurge in the research on nanoparticles and their potential application as antimicrobials[1].

Nanotechnology finds its application in various areas of medicine ranging from diagnosis, therapeutic drug delivery to treatment of many diseases. Silver nanoparticles (AgNPs) are one of the promising products in the field of nanotechnology because of its application as antimicrobials, therapeutics, biomolecular detection and catalysis [2].The most widely used and known applications of silver and AgNPs are in the medical industry. These include topical ointments and creams containing silver to prevent the infection of burns and open wounds [3].

Microbial synthesis of nanoparticles is a green chemistry approach that interconnects nanotechnology and microbial biotechnology. Biosynthesis of gold, silver, gold-silver alloy, selenium, tellurium, platinum, palladium, silica, titania, zirconia, quantum dots, magnetite and uraninite nanoparticles by bacteria, actinomycetes, fungi, yeasts and viruses have been reported. However, despite the stability, biological nanoparticles are not monodispersed and the rate of synthesis is slow. To overcome these problems, several factors such as microbial cultivation methods and the extraction techniques have to be optimized and thecombinatorial approach such as photobiological methods may be used [4].

Fungi have only been used to produce a few types of nanoparticles, and research in this area has only gained attention in the last few years. The main advantages of using fungi over bacteria for NPs synthesis are: their large biomass enables easy handling during biosynthesis [5]. High metal tolerance and economic viability [4]. Bioaccumulation ability and larger protein secretions [6]. Ease of scale up andhigh wall binding ability [7].

The purpose of the present study involves the extracellular biosynthesis of AgNPs using pathogenic bacteria like Staphylococcus aureus, Staphylococcusepidermidis and Klebsiella Pneumoniae and pathogenic fungi like Fusarium sp. and Aspergillus flavus; Moreover evaluation of their antimicrobial activity against various human pathogens and their capability of enhancing some commercial antibiotics.

\section{Materials and Methods}

\subsection{Preparation of bacterial and fungal cultures}

Staphylococcus aureus 29737 ATCC,Staphylococcus epidermidis 12228 ATCC,Klebsiella pneumoniae 700603 ATCC,Fusarium sp. and Aspergillus flavuswere provided from Microbiology Laboratory of Applied Studies Center of Medical Plants (National Organization for Drug Control and Research), bacterial cultures maintained in Mueller-Hinton medium and fungal cultures maintained in potato dextrose 


\section{International Journal of Science and Research (IJSR) \\ ISSN (Online): 2319-7064}

Index Copernicus Value (2015): 78.96 | Impact Factor (2015): 6.391

agar as well as subcultured from time to time to regulate its viability during study period.

\subsection{Biosynthesis of silver nanoparticles by Bacteria}

Bacteria cultures were freshly inoculated on Mueller-Hinton broth and incubated for 24 hours at $37^{\circ} \mathrm{C}$. The culture was centrifuged at 12,000 rpm for 5 minutes, and the supernatant was used for the synthesis of silver nanoparticles (AgNPs). Deionized water was used as solvent in the synthesis of AgNPs. The supernatant was added separately to the reaction vessel containing silver nitrate $\left(\mathrm{AgNO}_{3}\right)$ at concentrations of $1 \mathrm{mM}, 2 \mathrm{mM}$ and $3 \mathrm{mM}(1 \% \mathrm{v} / \mathrm{v})$. The reaction between this supernatant and $\mathrm{Ag}+$ ions was carried out in bright conditions for 5 minutes [8].

\subsection{Biosynthesis of silver nanoparticlesby fungi}

Erlenmeyer flasks $(500 \mathrm{ml})$ contains $200 \mathrm{ml}$ of sterile potato dextrose broth were then inoculated with $5 \mathrm{~mm}$ disks taken from Fusarium sp. andAspergillus flavus (7days-old). The flasks were incubated in the dark at $25 \pm 2{ }^{\mathrm{O}} \mathrm{C}$ for 1 week. For silver nanoparticles (AgNPs) bioproduction, the culture was filtered (Whatman filter paper No.1) at the end of incubation period to separate the biomass from filtrate followed by extensive washing with deionized water to remove any medium component from biomass. Typically $20 \mathrm{~g}$ of fresh biomass was brought in contact with $100 \mathrm{ml}$ of deionized water for $72 \mathrm{hrs}$ at $28 \pm 2{ }^{\circ} \mathrm{C}$ in an Erlenmeyer flask. After incubation cell filtrates was obtained by passing through Whatman filter paper No.1 and $50 \mathrm{ml}$ of Fusarium sp. andAspergillus flavus cell free filtrates were completed to $100 \mathrm{ml}$ of $1 \mathrm{mM}$ of $\mathrm{AgNO}_{3}$ in $250 \mathrm{ml}$ Erlenmeyer flasks. Positive controls containing cell free filtrate without silver nitrate and only $1 \mathrm{mM}$ silver nitrate as negative control were also maintained [9].

\subsection{Estimation and Characterization of silver nanoparticles}

\subsubsection{UV-Vis Spectrometry}

The UV-visual spectra of the samples were recorded by spectrophotometer (Nicolet evolution 100, Cambridge) with digital data acquisition, wavelength range $220-600 \mathrm{~nm}$. The UV spectrophotometer present in biochemistry laboratory of Applied Studies Center of Medical Plants (National Organization for Drug Control and Research).

\subsubsection{Fourier Transformer Infra Red (FT-IR)}

Theinstrument used is AKX0901119012A0607, genesis series Nicolet IS-10 F, Infrared spectrophotometer (IR) in Egyptian Petroleum Research Institute (EPRI).

\subsubsection{Dynamic Light Scattering}

Technique in physics that can be used to determine the size distribution profile of small particles in suspension or polymers in solution. When light hits small particles, the light scatters in all directions (Rayleigh scattering) as long as the particles are small compared to the wavelength (below $250 \mathrm{~nm}$ ). The scattering intensity fluctuates over time. This fluctuation is due to the fact that the small molecules in solutions are undergoing Brownian motion, the larger the particle, the slower the Brownian motion will be
[10]. The size and size distribution of particles in the colloids were measured using a Nano ZS zetasizer system Malvern Instruments in Egyptian Petroleum Research Institute (EPRI). Measurement parameters were as follows: a laser wavelength of $633 \mathrm{~nm}(\mathrm{He}-\mathrm{Ne})$, a scattering angle of $173^{\circ} \mathrm{C}$ (fixed-without changing possibility), a measurement temperature of $25^{\circ} \mathrm{C}$, a medium viscosity of $0.8872 \mathrm{mPa} . \mathrm{s}$ and a medium refractive index of 1.330 , and material refractive index of 1.59. Before DLS measurement, the colloid was passed through a $0.2 \mu \mathrm{m}$ polyvinylidene fluoride (PVDF) membrane. The sample was loaded into quartz microcuvette.

\subsubsection{Transmission Electron Microscopy (TEM)}

TEM was performed using JEOL-JEM 2100 Electron microscope operating at $200 \mathrm{KV}$ in Egyptian Petroleum Research Institute (EPRI).TEM studies were done at magnification $1.5 \mathrm{X}$ and resolution up to $0.143 \mathrm{~nm}$. Samples were prepared by placing a drop of solution with the silver nanoparticles (AgNPs) on carbon-coated TEM grids. The films on the TEM grids were allowed to dry at room temperature before analysis.

\subsubsection{Determination of antibacterial activity by well diffusion method}

The AgNPs synthesized from bacteria and fungi was tested for its antibacterial activity against pathogenic bacteria such as Staphylococcus epidermidis, Staphylococcus aureus, Klebsiella pneumoniae,Escherichiacoli and Pseudomonas aeruginosa by standard well diffusion method in MuellerHinton Agar (MHA) plates. Pure cultures of bacterial pathogens were grown in nutrient broth at $37^{\circ} \mathrm{C}$ for $18-24$ hours. Wells were made on the Mueller-Hinton agar plates using a gel puncture with diameter $4 \mathrm{~mm}$. The plates were inoculated by swabbing the bacterial pathogens to create a confluent lawn of bacterial growth. Then $100 \mu \mathrm{l}$ of the biosynthesized AgNPs solution were, poured on to corresponding well using a micropipette. As control $100 \mu \mathrm{l}$ of $1 \mathrm{mM} \mathrm{AgNO} 3$ solution were poured on to control well. After incubation at $37^{\circ} \mathrm{C}$ for 24 hours, diameter of zone of inhibition in millimeter around each well was measured[11].The assay was repeated in triplicate.

\subsection{Synergistic antibacterial activity combined with antibiotics}

Antibacterial enhancing activity of biosynthesized silver nanoparticles in combination with some important commercial antibiotics was also evaluated as per disk diffusion method. In this method, the standard antibiotic discs with concentrations $10 \mu \mathrm{g}$ ampicillin, $30 \mu \mathrm{g}$ chloramphenicol, $30 \mu \mathrm{g}$ tetracycline, $30 \mu \mathrm{g}$ cefotaxime and piperacillin/tazobactam $110 \mu \mathrm{g}$ (Oxoid manufacture) were impregnated with different biosynthesized silver nanoparticles (10 $\mu \mathrm{l}$ AgNPs) byS.aureus, S.epidermidis and K.pneumoniaeand placed onto Mueller-Hinton agar inoculated with test organisms (S.aureus, S.epidermidis, K.pneumoniae, E.coli andP.aeruginosa). These plates were then incubated at $37^{\circ} \mathrm{C}$ for 24 hours. The formation of zone inhibition (if any) was observed and measured in millimeters and compared with Control (antibiotic discs without silver nanoparticles). In case of absence zone of inhibitionthe standard diameterof antibiotic itself was $6 \mathrm{~mm}$.

\section{Volume 6 Issue 1, January 2017




\section{International Journal of Science and Research (IJSR) \\ ISSN (Online): 2319-7064}

Index Copernicus Value (2015): 78.96 | Impact Factor (2015): 6.391

\section{Results and Discussion}

\subsection{UV-Vis Spectrometry :}

The formation and stability of the reduced AgNPs in thecolloidal solution was monitored by using UV-Vis spectralanalysis. It is one of the importanttechniques to ascertain the formation of metal nanoparticles, provided surface plasmon resonance exists for the metal. The reaction of silver nitrate solution with the culture supernatant $K$. pneumoniae, $S$. epidermidisand $S$. aureus started within a few minutes and the color of solution turned to yellowish brown, indicating the formation of AgNPs. The observation indicated that the reduction of the $\mathrm{Ag}+$ ions took place extracellularly (Figure $1 \mathrm{~A}-\mathrm{F}$ ).

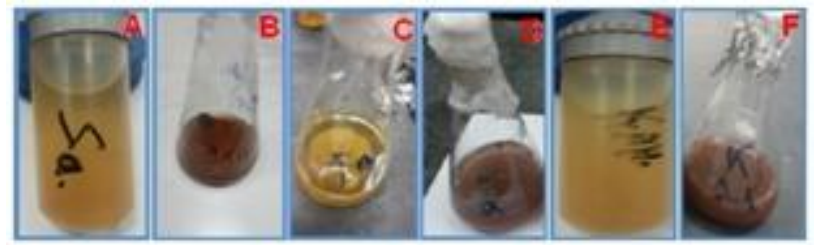

Figure 1: The conversion of silver nitrate to nano silver byStaphylococcus aureus (A- Culture, B- AgNPs synthesis); Staphylococcus epidermidis(C- Culture, DAgNPs synthesis) and Klebsiella pneumoniae(E- Culture, FAgNPs synthesis) using culture supernatant

Also aqueous silver nitrate ions were reduced during exposure to the Fusarium sp.and Aspergillus flavus cell free filtrate. The color of the reaction mixture changed from pale yellow to yellowish brown which indicates the formation of silver nanoparticles. Silver nanoparticles showed yellowish brown color solution after $72 \mathrm{hrs}$ of incubation and the color increase by time (Figure $2 \mathrm{~A}-\mathrm{F}$ ).
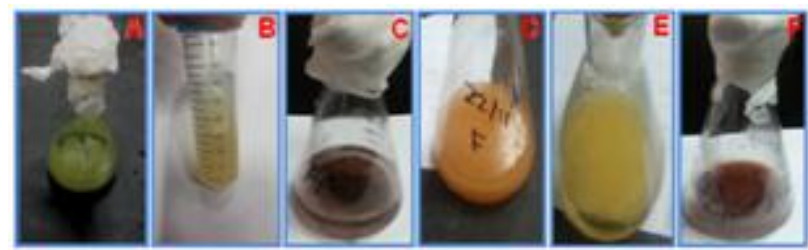

Figure 2: The conversion of silver nitrate to nano silver by Aspergillus flavus (A- in potato dextrose broth, B- cell free filtrate, $\mathrm{C}$-cell free filtrate after addition $\mathrm{AgNO}_{3}$ ) and Fusarium sp. (D- in potato dextrose broth, E- cell free filtrate F- cell free filtrate after addition $\mathrm{AgNO}_{3}$ )

Also the color change from pale yellow to dark brown colorobserved by[12] when cell free extract of K.pneumoniae challenged with $1 \mathrm{mM}$ and $2 \mathrm{mM} \mathrm{AgNO}_{3}$ and the color intensity increased with increasing incubation period. Beside that control without silver ions showed no change in color of the cell filtrates when incubated under the same conditions which agree totally with our results. Also the brown color of silver nanoparticles solution synthesized by E.coli observed by [13], and they explained that cells in the mid of exponential phase or starting range of stationary phase of culture (maximum reproduction of microorganism) produce maximum activity of enzymes involved in aggregation and reduction of silver ions to produce silver nanoparticles. In that concern, [14] showed that the synthesis of maximum cadmium sulfide during the stationary phase. Their results are suggesting that the formation silver nanoparticle has maximum activity at stationary phase of Bacillus licheniformis.

TheUV-Vis spectra recorded from449nm for culture supernatant of S.aureus when it subjected on $1 \mathrm{mMof}$ $\mathrm{AgNO}_{3}$ and broad peaks was noted around $422 \mathrm{~nm}$ and $420 \mathrm{~nm}$ when culture supernatant of $K$. pneumoniaeand $S$. epidermidiswas subjected to $1 \mathrm{mM}$ of $\mathrm{AgNO}_{3}$ subsequently as in (Figure 3A, B and C). Jeevan et al. [15] observed a characteristic strong broad peak located between 420 and $430 \mathrm{~nm}$ that confirmed the biosynthesis of AgNPs by Pseudomonas aeruginosa that agree with our results. It has been hypothesized that nitrate reductase enzyme shuttle electron from nitrate to the metal group and its role in biosynthesis of silver nanoparticles.Also UV-Vis spectra of Fusarium sp. and Aspergillus flavus cell free filtrates showed maximum absorption peaks (SPR) at 419.60nm and $421 \mathrm{~nm}$ subsequently (Figure 1D and 1E).

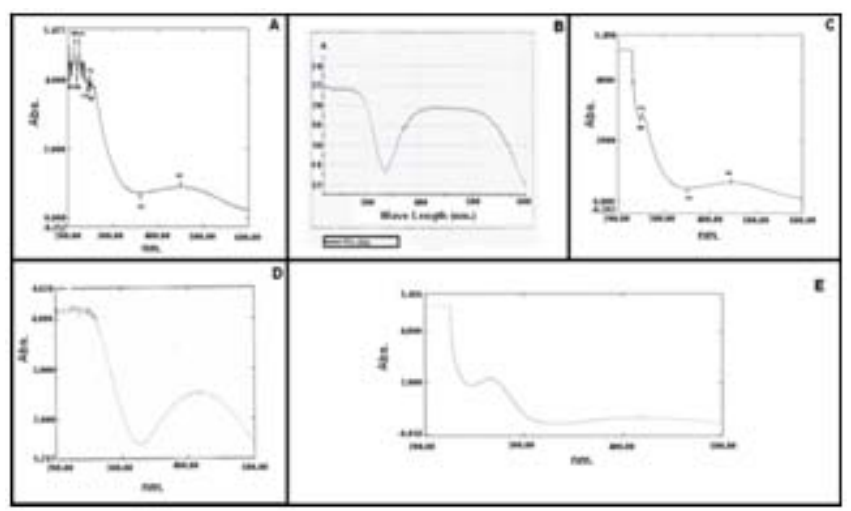

Figure 3: Synthesis of AgNPs by: -A)culture supernatant of Staphylococcus aureus;B) culture supernatant of Klebsiella pneumoniae;C)culture supernatant of Staphylococcus epidermidis;D)cell free filtrate of Aspergillus flavus and

E)cell free filtrateof Fusarium sp.by using $1 \mathrm{mM}$ of $\mathrm{AgNO}_{3}$

\subsection{Fourier Transformer Infra Red (FT-IR)}

FT-IR spectrum analysis of silver nanoparticles synthesized by $S$. aureus showed intense absorption bands at 3441.75 , $2923.99,1630.94,1384.35,1034.41$ and $539.41 \mathrm{~cm}^{-1}$ as in (Figure 4A). Silver nanoparticles synthesized by S.epidermidis showed intense absorption bands at 3290.76 , $2925.31,1629,1539.31,1384.8,1236.3,1077.8$ and $549 \mathrm{~cm}^{-}$ ${ }^{1}$ as in (Figure 4B). Also,silver nanoparticles synthesized by K.pneumoniae showed intense absorption bands at 3420 , $2926.35,1626.8,1386.6,1317.5$ and $670 \mathrm{~cm}^{-1}$ as in Figure (4C). The band around 3420, 3290 and $3441 \mathrm{~cm}^{-1}$ attributes almost entirely to the $\mathrm{N}-\mathrm{H}$ stretch vibrations of the peptide linkages or hydroxyl group of carboxylic acid. Further, the signature of stretching vibrations of methylene groups of proteins was noticed at bands number (2923, 2925 and 2926 $\mathrm{cm}^{-1}$ ). The presence of amide carbonyl stretching referred to the bands number $\left(1630.94,1629\right.$ and $\left.1626.8 \mathrm{~cm}^{-1}\right)$. Thus FT-IR spectrum signatures showed that protein component resulting from nitrate reductase enzyme present in the sample is responsible for reduction of silver ions. It is well known that protein is involved in binding and stabilizing of silver nanoparticles. Also, Jayalakashmi and Dinakaran 


\section{International Journal of Science and Research (IJSR) \\ ISSN (Online): 2319-7064 \\ Index Copernicus Value (2015): 78.96 | Impact Factor (2015): 6.391}

[16]showed intense bands by FT-IR of silver nanoparticles synthesized by marine E. coli (3410 and $2940 \mathrm{~cm}^{-1}$ )referring to primary and secondary amines, the presence of amide carbonyl stretching referred to the bands (1629, 1637 and $\left.1654 \mathrm{~cm}^{-1}\right)$. They presumed the protein as reducing and capping agent forming stable and control shaped silver nanoparticles that agreed with our results. It also confirmed by [17] the protein component of nitrate reductase enzyme is responsible for formation of silver nanoparticles associated with subtle variations in biological components of the culture supernatant of $P$. aeruginosa since nitratereduction is the phenotypic biochemical characteristic of this culture and the capping is possibly due to the rhamnolipids present in the culture supernatant.

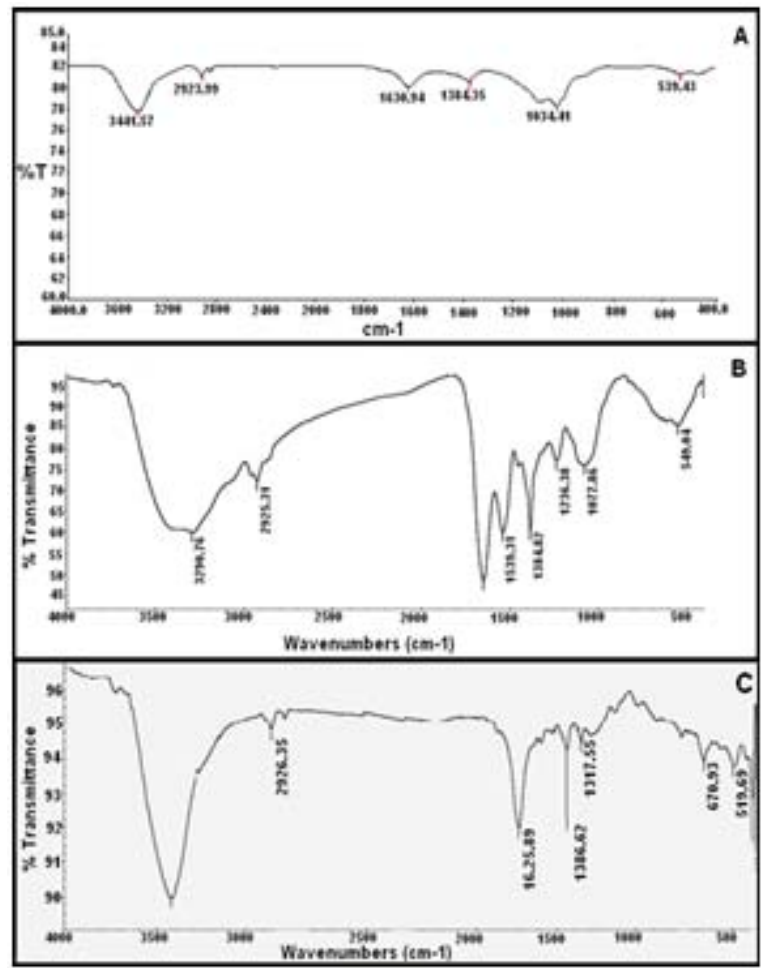

Figure 4: FTIR recorded from spectra of AgNPs synthesized by culture supernatant of A) Staphylococcus aureus; B) Klebsiella pneumoniaeand C) Staphylococcus epidermidis

The FTIRspectrum of $A$. flavus cell free filtrate after adding silver nitrate is included in (Figure 5A). Data revealed two bands $\left(1643.34\right.$ and $\left.1543 \mathrm{~cm}^{-1}\right)$ that corresponds to the bending vibrations of the amide I and amide II bands of the proteins respectively; while their corresponding stretching vibrations were seen at $\left(3440\right.$ and $\left.2926 \mathrm{~cm}^{-1}\right)$ respectively and $1247 \mathrm{~cm}^{-1} \mathrm{C}-\mathrm{O}$ stretching vibration of carboxylic acids or glycogen. These results revealed the involvement of $\mathrm{C}=\mathrm{O}$, amide I and amide II in reduction of silver ion and capping of silver nanoparticles. AgNPs synthesized by cell free filtrate of Fusarium sp.,(Figure 5B) showed band at 3445 $\mathrm{cm}^{-1}$ is attributed to $\mathrm{O}-\mathrm{H}$ and $\mathrm{N}-\mathrm{H}$ stretching and the band at $2088.5 \mathrm{~cm}^{-1}$ is assigned to the stretching vibration of amide II. Whereas bending vibration of amid I and amide II were observed at (1636 and $1461 \mathrm{~cm}^{-1}$ ) respectively, the band at $1161 \mathrm{~cm}^{-1}$ is stretching vibration of carboxylic acids or glycogen. Beside that[18] purified nitrate reductase from Fusarium oxysporum and a peptide, phytochelatin, for the in vitro synthesis of silver nanoparticles in the presence of a co-factor, NADPH and the nanoparticles were stabilized by the capping peptide, phytochelation.

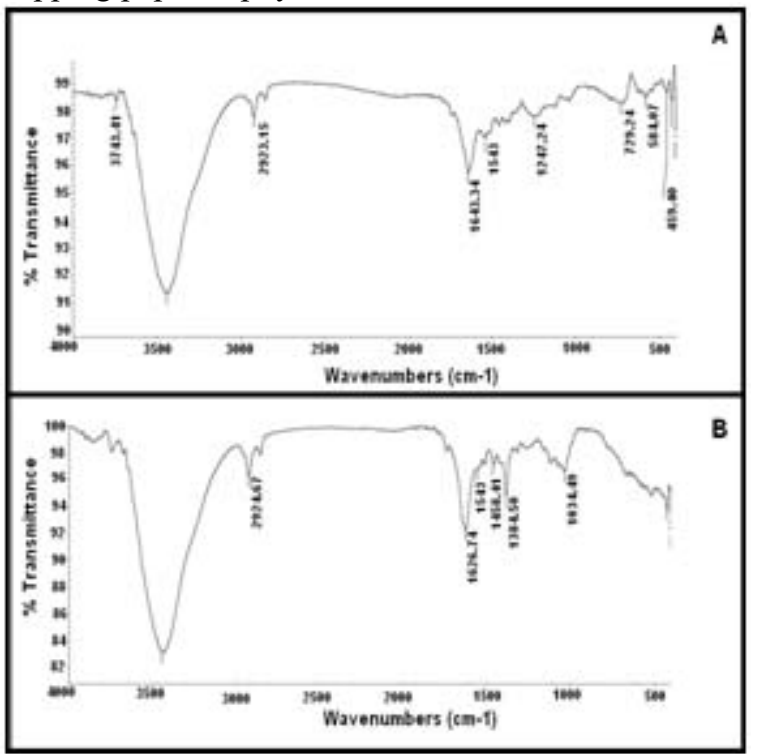

Figure 5: FTIR recorded from spectra of AgNPs synthesized by Cell free filtrate of A)Aspergillus flavusand B)Fusarium sp.

\subsection{Dynamic Light scattering}

The curves of size distribution demonstrate that diameter of AgNPs synthesized by $S$. aureus is around $58.76 \mathrm{~nm}$ (Figure $6 \mathrm{~A}$ ), by $K$. pneumoniaeis around $78.82 \mathrm{~nm}$ (Figure $6 \mathrm{~B}$ ) and by $S$. epidermidis isaround $91 \mathrm{~nm}$ (Figure 6C). However The curves of size distribution demonstrate that diameter of AgNPs synthesized by Fusarium sp. is around $122.4 \mathrm{~nm}$, and by Aspergillus flavus is around 78.82nm (Figure4D and 4E). Measurements parameters were as follows: dispersant $\mathrm{RI}=1,330$; viscosity $=0,8872 \mathrm{cP}$; temperature $=$ $25^{\mathrm{O}} \mathrm{C}$. Measurements uncertainties were calculated as the standard deviation as in figures (7A, B, C, D and E).



Figure 6: Size distribution curve of AgNPs by DLS method repeated three times for the sample A) Staphylococcus aureus;B)Klebsiella pneumoniae; C)Staphylococcus epidermidis; D) Fusarium sp. and E)Aspergillus flavus

\section{Volume 6 Issue 1, January 2017 www.ijsr.net}


International Journal of Science and Research (IJSR)

ISSN (Online): 2319-7064

Index Copernicus Value (2015): 78.96 | Impact Factor (2015): 6.391



Figure 7: Static graph for size distribution of AgNPs by DLS method for the sample A) Staphylococcus aureus

B)Klebsiella pneumoniae; C)Staphylococcus epidermidis; D) Fusarium sp. and E)Aspergillus flavus

The radius of silver nanoparticle (AgNPs) by S. aureus is $29.36 \mathrm{~nm}$ for $18.8 \%$ mean number of the sample. The radius of silver nanoparticle (AgNPs) by K.pneumoniae is $39.41 \mathrm{~nm}$ for $29 \%$ the mean number of the sample. The radius of silver nanoparticle (AgNPs) by $S$. epidermidis is $45.5 \mathrm{~nm}$ for $23.9 \%$ the mean number of the sample. The radius of silver nanoparticle by Fusarium sp. is $29.36 \mathrm{~nm}$ for $17.9 \%$ mean number of the sample. The radius of silver nanoparticle by Aspergillus flavus is $39.41 \mathrm{~nm}$ for $23.7 \%$ the mean number of the sample.

Dynamic Light Scattering (DLS) depend on the light interaction with particle, large particles can screen the smaller one as [19]explained that Sample polydispersity can distort the results, and we could not see the real populations of particles because big particles presented in the sample can screen smaller ones.

\subsection{Transmission Electron Microscope(TEM):}

TEM is powerful method to determine the size of nanoparticles. TEM analysis showed that most particles synthesized by $S$. aureus had a size of $\sim 11 \mathrm{~nm}$ with spherical shape. Most particles synthesized by $K$. pneumoniae had a size of mean average of $-16.88 \mathrm{~nm}$ with spherical shape. AgNPs synthesized by $S$. epidermidis had a size of mean average $-29.9 \mathrm{~nm}$ with spherical shape (Figure $8 \mathrm{~A}, \mathrm{~B}$ and C).TEM images for AgNPsof Fusarium sp.(Figure 8 D) showed spherical shape to some ellipsoidal with little assembling in the size range between 7.9 and $48.43 \mathrm{~nm}$. The mean average size is - $23.4 \mathrm{~nm}$. On other hand, TEM images of Aspergillus flavus AgNPs (Figure $8 \mathrm{E}$ ) showed AgNPs of varied shaped. It contains spherical, irregular, rod and few triangle shapes and also aggregates of nanoparticles. The size of AgNPs ranged between 13.11 and $48.90 \mathrm{~nm}$ with mean average size is - $23.4 \mathrm{~nm}$ which is in agreement with the results of [20] showed spherical, irregular and few triangles shaped silver nanoparticles and also aggregates of nanoparticles to form rosette shape were observed and the nanoparticles were 23.88 in size.

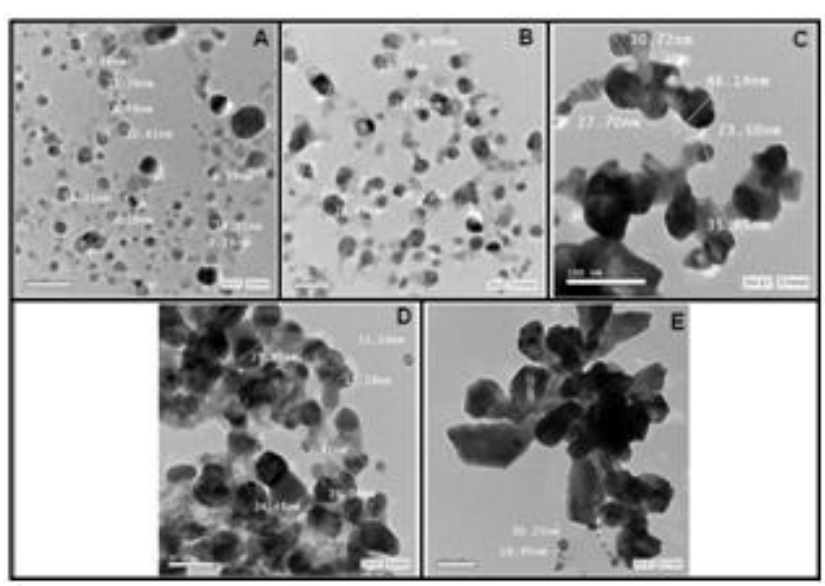

Figure 8: TEM image of developed AgNPs by A)Staphylococcus aureus;B)Klebsiella pneumoniae; C)Staphylococcus epidermidis; D) Fusarium sp. and E)Aspergillus flavus

In our results, it's clear that the size of silver nanoparticles synthesized in range between 5 and $45 \mathrm{~nm}$,also spherical silver nanoparticles synthesized by bacteria as Aeromonas sp. SH10, E. cloacae, K. pneumoniae, E. coli, Bacilluslicheniformis and Morganella $s p$ with size rangedbetween6.4 and $52.5 \mathrm{~nm}$, fungi asFusarium oxysporum in the range of $5 \sim 50 \mathrm{~nm}$ andcyanobacteria as Spirulinaplatensis and Nostoc sp. in the range of $5 \sim 40 \mathrm{~nm}$ that agree with our results [4][21][22].

\subsection{Antibacterial activity of AgNPs synthesized by Pathogenic Bacteria and Fungi:}

The antibacterial activity of biosynthesized silvernanoparticles was performed against both gram positive bacteria (Staphylococcus aureus,Staphylococcus epidermidis) and gram negative bacteria(Klebsiellapneumoniae, E.coli and Pseudomonas aeruginosa)by well diffusion method.The AgNPs synthesized by pathogenic bacteria and fungi showed excellent antibacterial activity againstall tested bacterial strains at volume of $100 \mu \mathrm{l} /$ well compared to silver nitrate solution as in Table (1).Theivasanthi and Alagar [23]agree with our study by showing that silver nanoparticles have antibacterial activities more than silver.

In the present investigation, after 24 hours of incubation, AgNPs synthesized by bacterial supernatant of Klebsiella pneumonia give highest inhibition zone $(19 \mathrm{~mm})$ followed by AgNPs synthesized by bacterial supernatant of $S$. epidermidis against $S$. aureus $(16 \mathrm{~mm})$. Beside that AgNPs synthesized by bacterial supernatant of Klebsiella pneumonia give highest inhibition zone (20.3 and $16.3 \mathrm{~mm})$ followed by AgNPs synthesized by bacterial supernatant of $S$. aureus (19.6 and $17.3 \mathrm{~mm}$ ) against $S$. epidermidis and $E$. coli subsequently. 


\section{International Journal of Science and Research (IJSR) \\ ISSN (Online): 2319-7064 \\ Index Copernicus Value (2015): 78.96 | Impact Factor (2015): 6.391}

Table 1: Antibacterial activity of AgNPs prepared by pathogenic bacteria and Fungi against different pathogenic bacteria (Inhibition zone by $\mathrm{mm}$ )

\begin{tabular}{|c|c|c|c|c|c|c|}
\hline Tested organisms & $\begin{array}{c}\text { AgNO } \\
\text { control }\end{array}$ & $\begin{array}{c}\text { AgNPs by } \\
\text { S. aureus }\end{array}$ & $\begin{array}{c}\text { AgNPs by } S . \\
\text { epidermidis }\end{array}$ & $\begin{array}{c}\text { AgNPs by } \text {. } \\
\text { pneumoniae }\end{array}$ & $\begin{array}{c}\text { AgNPs } \\
\text { byFusarium } \\
\text { sp. }\end{array}$ & $\begin{array}{c}\text { AgNPs by } \\
\text { A. flavus }\end{array}$ \\
\hline S. aureus & 11 & 15.3 & 16 & 19 & 13.5 & 15 \\
\hline S. epidermidis & 11 & 19.6 & 15.5 & 20.3 & 15.5 & 15 \\
\hline P. aeruginosa & 11 & 17 & 17 & 16 & 11 & 11 \\
\hline K. pneumoniae & 10.6 & 16.3 & 16 & 16 & 14.6 & 15 \\
\hline E. coli & 10 & 17.3 & 13.6 & 16.3 & 15.5 & 13 \\
\hline
\end{tabular}

Concerning other gram negative bacteria like Pseudomonas aeruginosa, Klebsiella pneumoniae, AgNPs synthesized by bacterial supernatant of $S$. aureus and $S$. epidermidis give the highest inhibition zone (17 and $16 \mathrm{~mm}$ ) compared to other biosynthesized silver nanoparticles. On other hand AgNPs synthesized by cell free filtrate of Fusariumsp. and A. flavusshow lowest inhibition zone against gram positive and negative bacteria compared to AgNPs synthesized by bacteria supernatant (Table 1).The mechanism of the bactericidal effect of silver nanoparticles is not very wellknown. It is believed that cellular proteins become inactive after treatment with silver nanoparticles. Silver nanoparticles after penetration into the bacteria have inactivated their enzymes, generating hydrogen peroxide and caused bacterial cell death.Heavy metals are toxic and react with proteins, therefore they bind protein molecules; as a result cellular metabolism is inhibited causing death of microorganism.It is known that silver sources such as silver nitrate and silver sulfadiazine release $\mathrm{Ag}^{+}$only but high activity of silver nanoparticles is attributed to the release of $\mathrm{Ag}^{0}$ and $\mathrm{Ag}^{+}$clusters when they dissolve [24].It is assumed that the high affinity of silver towards sulfur and phosphorus is the key element of the antimicrobial effect due to the abundance of sulfur-containing proteins on the bacterial cell membrane, silver nanoparticles can react with sulfurcontaining amino acids inside or outside the cell membrane, which affects bacterial cell viability. Silver ions (particularly $\mathrm{Ag}^{+}$) released from silver nanoparticles can interact with phosphorus moieties in DNA, resulting in inactivation of DNA replication, or can react with sulfur-containing proteins, leading to the inhibition of enzyme functions. Inthe present study the diameter of Ag nanoparticles is 11, 16.8 and $29.9 \mathrm{~nm}$. The general understanding is that $\mathrm{Ag}$ nanoparticle of typically less than $20 \mathrm{~nm}$ diameters get attached to sulfur-containing proteins of bacterial cell membranes leading to greater permeability of the membrane, which causes the death of the bacteria [25].

\subsection{Synergistic antibacterial activity combined with antibiotic}

Due to overuse of antibiotics and growing problem of antibiotic resistance, nanoparticles are being researched as an alternative antibacterial agent, the inhibitory activity of the silver nanoparticles was evaluated against and their potency was assessed qualitatively by the presence of inhibition zone. Different pathogenic bacteria exhibit different susceptibilities to nanoparticles. The result obtained on the efficacy of silver nanoparticles (synthesized by Staphylococcus aureus, Klebsiella pneumoniaeand Staphylococcus epidermidis) in combination with antibiotics revealed overall increase of zone inhibition size which indicated the increase in antibacterial potential of all antibiotics against the test bacterial strains as in tables $(2,3$ and4). 


\section{International Journal of Science and Research (IJSR) ISSN (Online): 2319-7064 \\ Index Copernicus Value (2015): 78.96 | Impact Factor (2015): 6.391}

Table 2: Synergistic effect of different antibiotics with or without AgNPs synthesized by Staphylococcus epidermidis against some pathogenic bacteria

\begin{tabular}{|c|c|c|c|c|c|}
\hline \multirow[b]{2}{*}{ Types of Antibiotics } & \multirow{2}{*}{$\begin{array}{c}\text { Name of the } \\
\text { Antibiotics }\end{array}$} & \multirow[b]{2}{*}{ Pathogenic Bacteria } & \multicolumn{2}{|c|}{ Zone of Inhibition (mm) } & \multirow{2}{*}{$\begin{array}{c}\text { Increased } \\
\text { ZoneSize }(\mathrm{mm})\end{array}$} \\
\hline & & & $\mathrm{Ab}^{*}$ & $\mathrm{Ab}+\mathrm{AgNPs}$ & \\
\hline \multirow{5}{*}{$\begin{array}{l}\text { Cephalosporins } \\
3^{\text {rd }} \text { generation }\end{array}$} & \multirow{5}{*}{ Cefataxime } & S.aureus & 22 & 23 & 1 \\
\hline & & E.coli & 28 & 30 & 2 \\
\hline & & S. epidermidis & 14 & 18 & 4 \\
\hline & & K.pneumoniae & Nil & 7 & 1 \\
\hline & & P.aeruginosa & Nil & 7 & 1 \\
\hline \multirow{10}{*}{ Sulphonamides } & \multirow{5}{*}{ Chloramphenicol } & S.aureus & 25 & 31.6 & 6.6 \\
\hline & & E.coli & 25 & 28 & 3 \\
\hline & & S. epidermidis & 25 & 26 & 1 \\
\hline & & K.pneumoniae & Nil & 1 & 4 \\
\hline & & P.aeruginosa & Nil & 7 & 1 \\
\hline & \multirow{5}{*}{ Tetracycline } & S.aureus & 36 & 38.5 & 2.5 \\
\hline & & E.coli & 22 & 26 & 4 \\
\hline & & S. epidermidis & 7 & 14 & 7 \\
\hline & & K.pneumoniae & Nil & 10 & 4 \\
\hline & & P.aeruginosa & Nil & 7 & 1 \\
\hline \multirow{5}{*}{ Penicillin } & \multirow{5}{*}{ Ampicillin } & S.aureus & 37.5 & 39 & 1.5 \\
\hline & & E.coli & 18 & 21 & 3 \\
\hline & & S. epidermidis & 13 & 15 & 2 \\
\hline & & K.pneumoniae & Nil & 8 & 2 \\
\hline & & P.aeruginosa & Nil & 7 & 1 \\
\hline \multirow{5}{*}{$\begin{array}{c}\text { Penicillin } \\
\text { Combination }\end{array}$} & \multirow{5}{*}{$\begin{array}{l}\text { Piperacillin/ } \\
\text { Tazobbactum }\end{array}$} & S.aureus & 34 & 37 & 3 \\
\hline & & E.coli & 22 & 27 & 5 \\
\hline & & S. epidermidis & 15 & 16 & 1 \\
\hline & & K.pneumoniae & 21 & 26 & 5 \\
\hline & & P.aeruginosa & 10 & 11 & 1 \\
\hline
\end{tabular}

Table 3: Synergistic effect of different antibiotics with or without AgNPs synthesized by Staphylococcus aureus against some pathogenic bacteria

\begin{tabular}{|c|c|c|c|c|c|}
\hline \multirow[b]{2}{*}{ Types of Antibiotics } & \multirow{2}{*}{$\begin{array}{l}\text { Name of the } \\
\text { Antibiotics }\end{array}$} & \multirow[b]{2}{*}{ Pathogenic Bacteria } & \multicolumn{2}{|c|}{ Zone of Inhibition $(\mathrm{mm})$} & \multirow{2}{*}{$\begin{array}{c}\text { Increased } \\
\text { ZoneSize (mm) }\end{array}$} \\
\hline & & & $\mathrm{Ab}^{*}$ & $\mathrm{Ab}+\mathrm{AgNPs}$ & \\
\hline \multirow{5}{*}{$\begin{array}{l}\text { Cephalosporins } \\
3^{\text {rd }} \text { generation }\end{array}$} & \multirow{5}{*}{ Cefataxime } & S.aureus & 22 & 24 & 2 \\
\hline & & E.coli & 28 & 30 & 2 \\
\hline & & S. epidermidis & 14 & 20 & 6 \\
\hline & & K.pneumoniae & Nil & 7 & 1 \\
\hline & & P.aeruginosa & Nil & 7 & 1 \\
\hline \multirow{10}{*}{ Sulphonamides } & \multirow{5}{*}{ Chloramphenicol } & S.aureus & 25 & 35 & 10 \\
\hline & & E.coli & 25 & 28 & 3 \\
\hline & & S. epidermidis & 25 & 26 & 1 \\
\hline & & K.pneumoniae & Nil & 10 & 4 \\
\hline & & P.aeruginosa & Nil & 8 & 2 \\
\hline & \multirow{5}{*}{ Tetracycline } & S.aureus & 36 & 39 & 3 \\
\hline & & E.coli & 22 & 26 & 4 \\
\hline & & S. epidermidis & 7 & 14 & 7 \\
\hline & & K.pneumoniae & Nil & 9 & 3 \\
\hline & & P.aeruginosa & Nil & 7 & 1 \\
\hline \multirow{5}{*}{ Penicillin } & \multirow{5}{*}{ Ampicillin } & S.aureus & 37.5 & 39 & 1.5 \\
\hline & & E.coli & 18 & 21 & 3 \\
\hline & & S. epidermidis & 13 & 17 & 4 \\
\hline & & K.pneumoniae & Nil & 7 & 1 \\
\hline & & P.aeruginosa & Nil & 7 & 1 \\
\hline \multirow{5}{*}{$\begin{array}{c}\text { Penicillin } \\
\text { Combination }\end{array}$} & \multirow{5}{*}{$\begin{array}{l}\text { Piperacillin/ } \\
\text { Tazobbactum }\end{array}$} & S.aureus & 34 & 39 & 5 \\
\hline & & E.coli & 22 & 27 & 5 \\
\hline & & S. epidermidis & 15 & 16 & 1 \\
\hline & & K.pneumoniae & 21 & 25 & 4 \\
\hline & & P.aeruginosa & 10 & 11 & 1 \\
\hline
\end{tabular}

Volume 6 Issue 1, January 2017 www.ijsr.net 


\section{International Journal of Science and Research (IJSR) ISSN (Online): 2319-7064 \\ Index Copernicus Value (2015): 78.96 | Impact Factor (2015): 6.391}

Table 4: Synergistic effect of different antibiotics with or without AgNPs synthesized by Klebsiella pneumoniae against some pathogenic bacteria

\begin{tabular}{|c|c|c|c|c|c|}
\hline \multirow{2}{*}{ Types of Antibiotics } & \multirow{2}{*}{$\begin{array}{l}\text { Name of the } \\
\text { Antibiotics }\end{array}$} & \multirow{2}{*}{ Pathogenic Bacteria } & \multicolumn{2}{|c|}{ Zone of Inhibition (mm) } & \multirow{2}{*}{$\begin{array}{c}\text { Increased } \\
\text { ZoneSize }(\mathrm{mm})\end{array}$} \\
\hline & & & $\mathrm{Ab}^{*}$ & $\mathrm{Ab}+\mathrm{AgNPs}$ & \\
\hline \multirow{5}{*}{$\begin{array}{l}\text { Cephalosporins } \\
3^{\text {rd }} \text { generation }\end{array}$} & \multirow{5}{*}{ Cefataxime } & S.aureus & 22 & 23 & 1 \\
\hline & & E.coli & 28 & 31 & 3 \\
\hline & & S. epidermidis & 14 & 17 & 3 \\
\hline & & K.pneumoniae & Nil & 7 & 1 \\
\hline & & P.aeruginosa & Nil & Nil & Nil \\
\hline \multirow{10}{*}{ Sulphonamides } & \multirow{5}{*}{ Chloramphenicol } & S.aureus & 25 & 28.5 & 2.5 \\
\hline & & E.coli & 25 & 26 & 1 \\
\hline & & S. epidermidis & 25 & 28 & 3 \\
\hline & & K.pneumoniae & Nil & 10 & 4 \\
\hline & & P.aeruginosa & Nil & 8 & 2 \\
\hline & \multirow{5}{*}{ Tetracycline } & S.aureus & 36 & 37 & 1 \\
\hline & & E.coli & 22 & 27 & 5 \\
\hline & & S. epidermidis & 7 & 12 & 5 \\
\hline & & K.pneumoniae & Nil & 8 & 2 \\
\hline & & P.aeruginosa & Nil & 9 & 3 \\
\hline \multirow{5}{*}{ Penicillin } & \multirow{5}{*}{ Ampicillin } & S.aureus & 37.5 & 39 & 1.5 \\
\hline & & E.coli & 18 & 21 & 3 \\
\hline & & S. epidermidis & 13 & 14 & 1 \\
\hline & & K.pneumoniae & Nil & 7.5 & 1.5 \\
\hline & & P.aeruginosa & Nil & Nil & Nil \\
\hline \multirow{5}{*}{$\begin{array}{c}\text { Penicillin } \\
\text { Combination }\end{array}$} & \multirow{5}{*}{$\begin{array}{l}\text { Piperacillin/ } \\
\text { Tazobbactum }\end{array}$} & S.aureus & 34 & 37 & 3 \\
\hline & & E.coli & 22 & 30 & 8 \\
\hline & & S. epidermidis & 15 & 16 & 1 \\
\hline & & K.pneumoniae & 21 & 27 & 6 \\
\hline & & P.aeruginosa & 10 & 11 & 1 \\
\hline
\end{tabular}

It was also observed that there was no zone inhibition in the control as some antibiotics alone in case of E.coli, $K$. pneumoniaeand P.aeruginosa.The highest increase zone size was observed for chloramphenicol $(6.6,10$ and $2.5 \mathrm{~mm})$ then piperacillin/tazobactum against S.aureus (3, 5and 3mm) for AgNPs by $S$. epidedrmidis, S.aureus and K.pneumoniae(Tables 2,3 and 4).On other hand tetracycline showed highest size increase against $S$. epidermidis ( 7,7 and $5 \mathrm{~mm}$ ). Also chloramphenicol with AgNPs showed high increase zone size with gram negative bacteria with K.pneumoniae.The diameter of inhibition zones for antibiotics in combination with silver nanoparticles showed significant increase in zone size in all cases.

Also Antibacterial activity of silver nanoparticles produced from two fungi (Fusarium sp. and A.flavus) were carried out using AgNPs alone and in combination of different commercially available antibiotics against five pathogenic bacteria using the disc diffusion method (Tables 5 and 6).

Table 5: Synergistic effect of different antibiotics with or without AgNPs synthesized by Fusarium sp.against some pathogenic bacteria

\begin{tabular}{|c|c|c|c|c|c|}
\hline \multirow{2}{*}{ Types of Antibiotics } & \multirow{2}{*}{$\begin{array}{l}\text { Name of the } \\
\text { Antibiotics }\end{array}$} & \multirow{2}{*}{ Pathogenic Bacteria } & \multicolumn{2}{|c|}{ Zone of Inhibition (mm) } & \multirow{2}{*}{$\begin{array}{c}\text { Increased } \\
\text { ZoneSize }(\mathrm{mm})\end{array}$} \\
\hline & & & $\mathrm{Ab}^{*}$ & $\mathrm{Ab}+\mathrm{AgNPs}$ & \\
\hline \multirow{5}{*}{$\begin{array}{c}\text { Cephalosporins } \\
3^{\text {rd }} \text { generation }\end{array}$} & \multirow{5}{*}{ Cefataxime } & S.aureus & 22 & 24.6 & 2.6 \\
\hline & & E.coli & 28 & 30 & 2 \\
\hline & & S. epidermidis & 14 & 14 & Nil \\
\hline & & K.pneumoniae & Nil & 11 & 5 \\
\hline & & P.aeruginosa & Nil & 9 & 3 \\
\hline \multirow{10}{*}{ Sulphonamides } & \multirow{5}{*}{ Chloramphenicol } & S.aureus & 25 & 30.3 & 5.3 \\
\hline & & E.coli & 25 & 26 & 1 \\
\hline & & S. epidermidis & 25 & 25 & Nil \\
\hline & & K.pneumoniae & Nil & 11 & 5 \\
\hline & & P.aeruginosa & Nil & 11 & 5 \\
\hline & \multirow{5}{*}{ Tetracycline } & S.aureus & 36 & 37.5 & 1.5 \\
\hline & & E.coli & 22 & 27 & 5 \\
\hline & & S. epidermidis & 7 & 12 & 5 \\
\hline & & K.pneumoniae & Nil & 10 & 4 \\
\hline & & P.aeruginosa & Nil & 10 & 4 \\
\hline \multirow{5}{*}{ Penicillin } & \multirow{5}{*}{ Ampicillin } & S.aureus & 37.5 & 39.5 & 1.8 \\
\hline & & E.coli & 18 & 20 & 2 \\
\hline & & S. epidermidis & 13 & 20 & 7 \\
\hline & & K.pneumoniae & Nil & 9.5 & 3.5 \\
\hline & & P.aeruginosa & Nil & 11 & 5 \\
\hline \multirow{5}{*}{$\begin{array}{c}\text { Penicillin } \\
\text { Combination }\end{array}$} & \multirow{5}{*}{$\begin{array}{l}\text { Piperacillin/ } \\
\text { Tazobbactum }\end{array}$} & S.aureus & 34 & 37.5 & 3.5 \\
\hline & & E.coli & 22 & 12 & -5 \\
\hline & & S. epidermidis & 15 & 14 & -1 \\
\hline & & K.pneumoniae & 21 & 24.5 & 2.5 \\
\hline & & P.aeruginosa & 10 & 11 & 1 \\
\hline
\end{tabular}

\section{Volume 6 Issue 1, January 2017 www.ijsr.net}




\section{International Journal of Science and Research (IJSR) \\ ISSN (Online): 2319-7064}

Index Copernicus Value (2015): 78.96 | Impact Factor (2015): 6.391

Table 6: Synergistic effect of different antibiotics with or without AgNPs synthesized by Aspergillus flavusagainst some pathogenic bacteria

\begin{tabular}{|c|c|c|c|c|c|}
\hline \multirow{2}{*}{ Types of Antibiotics } & \multirow{2}{*}{$\begin{array}{r}\text { Name of the } \\
\text { Antibiotics }\end{array}$} & \multirow{2}{*}{ Pathogenic Bacteria } & \multicolumn{2}{|c|}{ Zone of Inhibition (mm) } & \multirow{2}{*}{$\begin{array}{c}\text { Increased } \\
\text { ZoneSize }(\mathrm{mm})\end{array}$} \\
\hline & & & $\mathrm{Ab}^{*}$ & $\mathrm{Ab}+\mathrm{AgNPs}$ & \\
\hline \multirow{5}{*}{$\begin{array}{c}\text { Cephalospor } 3^{\text {rd }} \\
\text { generationins }\end{array}$} & \multirow{5}{*}{ Cefataxime } & S. aureus & 22 & 24.5 & 1.5 \\
\hline & & E. coli & 28 & 29 & 1 \\
\hline & & S. epidermidis & 14 & 20 & 6 \\
\hline & & K. pneumoniae & Nil & 7 & 1 \\
\hline & & P. aeruginosa & Nil & 9 & 3 \\
\hline \multirow{10}{*}{ Sulphonamides } & \multirow{5}{*}{ Chloramphenicol } & S. aureus & 25 & 29 & 4 \\
\hline & & E. coli & 25 & 26 & 1 \\
\hline & & S. epidermidis & 25 & 25 & Nil \\
\hline & & K. pneumoniae & Nil & 10 & 4 \\
\hline & & P. aeruginosa & Nil & 11 & 5 \\
\hline & \multirow{5}{*}{ Tetracycline } & S. aureus & 36 & 39.6 & 3.6 \\
\hline & & E. coli & 22 & 29 & 7 \\
\hline & & S. epidermidis & 7 & 12 & 5 \\
\hline & & K. pneumoniae & Nil & 7 & 1 \\
\hline & & P. aeruginosa & Nil & 10 & 4 \\
\hline \multirow{5}{*}{ Penicillin } & \multirow{5}{*}{ Ampicillin } & S. aureus & 37.5 & 41.5 & 3 \\
\hline & & E. coli & 18 & 19 & 1 \\
\hline & & S. epidermidis & 13 & 15 & 2 \\
\hline & & K. pneumoniae & 10 & 7 & 3 \\
\hline & & P. aeruginosa & Nil & 11 & 5 \\
\hline \multirow{5}{*}{ PenicillinCombination } & \multirow{5}{*}{ Piperacillin/Tazobbactum } & S. aureus & 34 & 37.6 & 3.6 \\
\hline & & E. coli & 22 & 12 & -10 \\
\hline & & S. epidermidis & 15 & 15 & Nil \\
\hline & & K. pneumoniae & 21 & 25 & 4 \\
\hline & & P. aeruginosa & 10 & 11 & 1 \\
\hline
\end{tabular}

Silver nanoparticles of cell free filtrate of $A$. flavus showed bactericidal activities in terms of inhibition zone (0$7 \mathrm{~mm})$. The highest increase zone size of AgNPs of cell free filtrate of A. flavus + tetracycline was in case of E. coli, $S$. epidermidis and $P$. aeruginosa, respectively. Also, the highest increase zone size of AgNPs of cell free filtrate of $A$. flavus + with chloramphenicol was in case of $S$. aureus, $K$. pneumonia and $P$. aeruginosa, respectively. Generally, tetracycline showed the highest increase in zone size with most different AgNPs against S. epidermidis, K. pneumoniae and in some cases with $P$. aeruginosa, choramphenicol with most different AgNPs showed the highest increase zone size against $S$. aureus.

Silver nanoparticles of cell free filtrate of Fusarium sp. showed mild bactericidal activities in terms of inhibition zone $(8-12 \mathrm{~mm})$. Also combination of ampicillin with silver nanoparticles synthesized by cell free filtrate of Fusarium sp. gave high increase zone size against $S$. epidermidis, K.pneumoniae. On other hand, the combination of AgNPs from Fusarium sp. + Piperacillin and tazobactum in case of $S$. epidermidis and E. coli gained high antagonistic effect.

Shaverdi et al. [26] studied the effect of silver nanoparticles alone and in combination with antibiotics on the bacteria. They synthesized the silver nanoparticle using Klebsiellapneumoniae and in combination with antibiotics on the S.aureus and E.coli bacteria. They observed a significant increase in antibacterial activity of antibiotics in presence of silver nanoparticles and there was highest synergistic effect of nanoparticles with erythromycin against S.aureus.Also,Fayaz et al. [27] observed that antibacterial activities of ampicillin and chloramphenicol were increased in the presence of Ag nanoparticles.

\section{Acknowledgment}

The authors would like to express the deepest appreciation to Dr. Amel F.M. Ismail; Drug Radiation Research Department, and Associated Prof. Dr. Sawsan M. ElSonbaty; Radiation Microbiology department, National Center for Radiation Research and Technology (NCRRT), Atomic Energy Authority, Nasr City, Cairo, Egypt, for the kind help in suggesting the work plane, preparation, characterization and valuable discussion of the prepared silver nanoparticles.

\section{References}

[1] M.K. Rai, A. Gade, A. Yadav, Biogenic nanoparticles: An introduction to what they are, how they are synthesized and their applications," in Metal nanoparticles in microbiology, M.K. Rai, and N. Duran (eds.). Springer-Verlag Berlin Heidelberg, Germany, 2011.

[2] M.K. Rai, A.P. Yadav, A.K. Gade, Silver nanoparticles as a new generation of antimicrobials," Biotechnology Advances, XXVII (1), pp.76-83, 2009.

[3] R.O. Becker, Silver ions in the treatment of local infections," Metal- Based Drugs, VI pp. 297-300, 1999.

[4] K.B. Narayanan, N. Sakthivel, Biological synthesis of metal nanoparticles by Microbes," Advances in Colloid and Interface Science, CLVI (1-2), pp.1-13, 2010.

[5] A.R. Binupriya, M. Sathishkumar, S.I. Yun, Biocrystalization of silver and gold ions by inactive cell filtrate Rhizopus stolonifer," Colloids and Surfaces B: Biointerfaces, LXXIX (2), pp. 531-534, 2010.

[6] L. Du, L. Xian, J.X. Feng, -Raipd Extra-/ intracellular biosynthesis of gold nanoparticles by the fungus 


\section{International Journal of Science and Research (IJSR) \\ ISSN (Online): 2319-7064 \\ Index Copernicus Value (2015): 78.96 | Impact Factor (2015): 6.391}

Penicillium sp.,"Journal of Nanoparticles Research, XIII, pp. 921-930, 2011.

[7] Z. Sheikhloo, M. Salouti, F. Katiraee, Biological synthesis of gold nanopartticle by fungus Epicoccum nigrum," Journal of Cluster Science, XXII (4), pp. 661$665,2011$.

[8] A. Nanda, M. Saravanan, Biosynthesis of silver nanoparticles from Staphylococcus aureus and its antimicrobial activity against MRSA and MRSE", Nanomedicine: Nanotechnology, Biology, and Medicine, V (4), pp. 452-456, 2009.

[9]

.M. Ghareib, M. Attia, N.M. Awad, M.Z. Matter, D. EL-kahky, Screening of Fusarium spp. resistance to silver ions for ability to synthesize silver nanoparticles from Egyptian soils", Global Advanced Research Journal of Medicine and Medical Science, IV (9), pp.366-382, 2015.

[10]B.J. Berne, and Pecora, R., Dynamic light scattering with applications to chemistry, biology and physics. Dover Publications, Inc., Mineola, New York 11501, USA, 2000.

[11]R. Thomas, A. Viswan, J. Mathew, E.K. Radhakrishnan, Evaluation of antibacterial activity of silver nanoparticles synthesized by a novel strain of marine Pseudomonas sp.",Nano Biomedicine and Engineering, IV, pp.139-143, 2012.

[12] A. Ratan, E. Gupta, R. Ragunathan, - \$nthesis of silver nanoparticles using Klebsiella pneumoniae and its biomedical applications",International Journal of Enhanced Research in Science Technology and Engineering, I (1), pp.1-7, 2012.

[13]K. Natarajan, S. Selvaraj, V.R. Murty, Microbial production of silver nanoparticles", Digest Journal of Nanomaterials and Biostructures, V (1), pp.135-140, 2010 .

[14] K. Kalimuthu, R. Suresh Babu, D. Venkataraman M. Bilal, S. Gurunathan, - Bosynthesis of silver nanocrystals by Bacillus licheniformis", Colloids and Surfaces B: Biointerfaces, LXV (1), pp.150-153, 2008.

[15]P. Jeevan, K. Ramya, A. Edith Rena, Extracellular biosynthesis of silver nanoparticles by culture supernatant of Pseudomonas aeruginosa", Indian Journal of Biotechnology, XI, pp. 72-76, 2012.

[16] S. Jayalakashmi, S. Dinakaran, Biosynthesis and characterization of silver nanoparticles by a marine strain Escherichia coli SJ101", International Journal of Innovation Research, I (1), pp. 1-35, 2013.

[17] C.G. Kumar, S.K. Mamidyala, Extracellular synthesis of silver nanoparticles using culture supernatant of Pseudomonas aeruginosa", Colloids and Surfaces B: Biointerfaces, LXXXIV, pp. 462-466, 2011.

[18] A.S. Kumar, M.K. Abyaneh, S.W. Gosavi, S.K. Kulkarni, R. Pasricha, A. Ahmad, M.I. Khan, Nitrate reductase- mediated synthesis of silver nanoparticles from $\mathrm{AgNO}_{3}$ ", Biotechnology Letter, XXIX (3), pp. 439-445, 2007

[19]E. Tomaszewska, K. Soliwoda, K. Kadziola, B. TkaczSzczesna, G. Celichowski, M. Cichomski, W. Szmaja, J. Grobelny, Đetection limits of DLS and UV-Vis spectroscopy in characterization of polydisperse nanoparticles colloids", Journal of Nanomaterials, http://dx.doi.org/10.1155/213/313081, 2013.
[20]R. Manimozhi, R. Anitha, Mycosynthesis of silver nanoparticles using aqueous extract of Aspergillus flavus mycelium and its characterization", International Journal of Pharmaceutics and Drug Analysis, II (9), pp. 734-739, 2014.

[21]K.V. Selvi, T. Sivakumar, Isolation and characterization of silver nanoparticles by Fusarium oxysporum", International Journal of Current Microbiology and Applied Science, I (1), pp. 56-62, 2012.

[22]E.A. Ahmed, E.H. Abdel Hafez, A.F.M. Ismail, S.M. Elsonbaty, H.S.Abbak, R.A.Salah El Din, Biosynthesis of Silver Nanoparticles by Spirulina platensis\&Nostoc sp.",Global Advanced Research Journal of Microbiology,IV (4), pp. 36-49, 2015.

[23] T. Theivasanthi, M. Alagar, -Ati-bacterial studies of silver nanoparticles", General Physics, Cornell University Library, http://arxiv.org/abs/1101.0348, 2011.

[24] M. Raffi, F. Hussain, T.M. Bhatti, J.I. Akhter, A. Hameed, M. Hasan, -Aribacterial characterization of silver nanoparticles against $E$. coli ATCC15224", Journal of Materials Science and Technology, XXIV (2), pp. 192-196, 2008.

[25] J.R. Morones, J.L. Elechiguerra, A. Camacho, K. Holt, J.B. Kouri, J.T. Ramirez, M.J. Yacaman, The bactericidal effect of silver nanoparticles", Journal of Nanotechnology, XVI, pp. 2346-2353, 2005.

[26] R.A. Shaverdi, S. Minaeian, R.H. Shahverdi, H. Jamalifar, A.A. Nohi, Rapid synthesis of silver nanoparticles using culture supernatants of Enterobacteria: a novel biological approach", Process Biochemistry, XLII, pp. 919-923, 2007.

[27] A.M. Fayaz, K. Balaji, M. Girilal, R. Yadav, P.T. Kalaichelvan, R. Venketesan, Biogenic synthesis of silver nanoparticles and their synergistic effect with antibiotics: a study against gram positive and gram negative bacteria", Nanomedicine: Nanotechnology, Biology and Medicine, VI (1), pp. 103-109, 2010.

\section{Volume 6 Issue 1, January 2017

